Islamic Gardens and Landscapes 
PENN STUDIES IN LANDSCAPE ARCHITECTURE

John Dixon Hunt, Series Editor

This series is dedicated to the study and promotion of a wide variety of approaches to landscape architecture, with special emphasis on connections between theory and practice. It includes monographs on key topics in history and theory, descriptions of projects by both established and rising designers, translations of major foreign-language texts, anthologies of theoretical and historical writings on classic issues, and critical writing by members of the profession of landscape architecture.

The series is the recipient of the Award of Honor in Communications from the American Society of Landscape Architects, 2006. 


\section{Islamic Gardens}

\section{and Landscapes}

D. Fairchild Ruggles 
Publication of this volume was assisted by a generous grant from The Getty Foundation.

Copyright $(2008$ University of Pennsylvania Press

All rights reserved. Except for brief quotations used for purposes of review

or scholarly citation, none of this book may be reproduced in any form

by any means without written permission from the publisher.

Printed in Canada on acid-free paper.

10987654321

Published by

University of Pennsylvania Press

Philadelphia, Pennsylvania 19104-4112

LIBRARY OF CONGRESS CATALOGING-IN-PUBLICATION DATA

Ruggles, D. Fairchild.

Islamic gardens and landscapes / D. Fairchild Ruggles.

p. cm. - (Penn studies in landscape architecture)

Includes bibliographical references and index.

ISBN-I3: 978-0-8122-4025-2 (hardcover : alk. paper)

ISBN-IO: 0-8I22-4025-I (hardcover : alk. paper)

I. Gardens, Islamic. I. Title.

SB 457.8.R85 2007

$712.0917^{\prime} 67-\mathrm{dc} 22$ 


\section{To my parents}

Jeanne Françoise Peter Ruggles and Thomas Morrill Ruggles 
